\title{
Isolation and Characterization of Bacterial Isolates from Psidium guajava Obtained from Local Markets of Patna and Their Antibiotic Sensitivity Test
}

\author{
Deepak Kumar Jha*, Ritu Raj**, Pravritti**, Samiksha**, Aditi**, Gulistan Parveen** and \\ Niti Yashvardhini $* * \dagger$ \\ *Department of Zoology, Patna University, Patna-800 005, Bihar, India \\ **Department of Microbiology, Patna Women's College, Patna, Bihar, India \\ $†$ Corresponding author: Niti Yashvardhini; nitiyashvardhini@gmail.com
}

Nat. Env. \& Poll. Tech. Website: www.neptjournal.com

Received: $16-02-2020$

Revised: $05-03-2020$

Accepted: 15-04-2020

Key Words:

Psidium guajava

Antibiotic resistant bacteria

Microbiological test

Bacterial isolates

\begin{abstract}
The study was conducted to investigate the presence of antibiotic resistant bacteria in guava, sold in the local markets of Patna. A total of twenty five fresh samples of guava were collected from five different market places in Patna city. Several microbiological tests were performed to assess the growth and type of bacteria. The colonies were isolated and identified as isolate 1 and 3 (identical to Staphylococcus spp.), isolate 2 (identical to Escherichia spp.) and isolate 4 and 5 (identical to Bacillus spp.) based on their cultural, morphological, Gram's staining and biochemical characteristics. Antibiotic susceptibility tests were conducted to detect their actual resistance capability. In the present study, S1 and S3 were found resistant to ampicillin, chloramphenicol, ofloxacin and intermediate to gentamycin while S2 was found resistant to ampicillin, chloramphenicol, gentamycin, ciprofloxacin, cephalexin and intermediate to ofloxacin. The isolates S4 and S5 were found sensitive to gentamycin, intermediate to chloramphenicol and resistant to ciprofloxacin. Results of this study showed that the guava samples obtained from different markets of Patna possess multidrug resistant bacteria.
\end{abstract}

\section{INTRODUCTION}

Guava (Psidium guajava) is widely distributed throughout the regions of India and also considered as popular indigenous fruit. It is most often called the "apple of the tropics" belonging to the family Myrtaceae (Shruthi et al. 2013). It possesses excellent medicinal properties with a pleasant aroma. Guava is a popular and important fruit consumed all over India for its easy availability, low cost and high nutritive value (Kaneria \& Chanda 2011). Fruits like guava, which are mostly eaten raw and are highly perishable, and can also be a source of several bacterial diseases due to their improper handling during storage and transportation. It exhibits antioxidant properties, recognized for its anti-allergic, antimicrobial, antidiabetic, anti-inflammatory significance, and is a rich source of vitamin C (Shruthi et al. 2013). It can also be used for the treatment of gastroenteritis, diarrhoea and dysentery as well as green mature guava is a rich source of pectin, calcium and phosphorus (Morton et al. 1987). India, due to its diverse climatic conditions and rich biodiversity is the natural habitat for varieties of fruit. Extending from the Himalayan belt in the north to the southern tropical belt, India offers much in terms of fruit diversity. Among Indian states, Bihar is one of the leading producers of guava (Dinesh \& Vasugi et al. 2010).
Improper manipulation and exposure to the environment such as soil, water and air can harbour a heterogeneous range of microorganisms (Sarker et al. 2018). Microorganisms, especially bacteria, thrive on the fresh guava fruits making them prone to several diseases. Consumption of such guava by humans can result in varieties of infection and associated health risks. Most microbes which are initially observed on whole fruit or vegetables are soil inhabitants (Andrews \& Harris 2000, Janisiewicz \& Korsten 2002). The worldwide use of antibiotics in different fields has created pressure to select resistance among infectious bacterial pathogen (Balotescu et al. 2003, Sharma et al. 2005). Public organization illustrates resistant bacteria as a disaster or a nightmare scenario that could have deleterious effects on human health (Viswanathan 2014).

The emergence of antibiotic resistant bacteria is a major concern of public health nowadays. The widespread misuse of antibiotics has led to an alarming increase of antibiotic resistant bacteria such as Staphylococcus spp., Pseudomonas spp., Streptococcus spp., Escherichia coli.

It is evident that not much attention has been paid to guava fruit safety, especially, in context of Patna (Bihar). Therefore, the main objective of the present study was to isolate bacterial spp. from different guava samples collected from different 
areas of Patna and to investigate their antibiotic resistant properties which are a major cause of several health issues.

\section{MATERIALS AND METHODS}

\section{Sample Collection}

Guava samples were collected from different regions of Patna (Table 1). The selected market places for sample collection were Patliputra colony, Kankarbagh, Boring road, Agamkuan and Bazar Samiti. The samples were collected in a sterilized zip lock bag with appropriate labelling.

\section{Isolation of Bacteria}

For the isolation of bacteria, samples were washed thoroughly with $10 \mathrm{~mL}$ of sterile PBS (phosphate buffer saline) solution. Inoculation through spreading was done on a nutrient agar plate (Sanders 2012) with different serially diluted sample (up to $10^{-4}$ dilution) and the plates were incubated at $37^{\circ} \mathrm{C}$ for 24 hours. The strains that were obtained on nutrient agar plates were again streaked on eosin methylene blue (EMB) selective media and incubated at $37^{\circ} \mathrm{C}$ for $24-48$ hours (Islam et al. 2014). The obtained colonies were pured by streaking on nutrient agar plates for further analysis.

\section{Bacterial Enumeration}

Colonies were enumerated using a colony counter by placing the plates on the colony counter and visualizing it as well as Total Viable Count (TVC) was calculated (Brugger et al. 2012).

\section{Cultural and Morphological Characterisation}

Plates were observed and colony morphology was recorded. The morphological characteristics like shape, colour, texture,

Table 1: Details of samples taken for the isolation of bacteria.

\begin{tabular}{|lll|}
\hline Name of market & Number of guava samples collected & Total \\
\hline Patliputra colony & 5 & 25 \\
Kankarbagh & 5 & \\
Boring road & 5 & \\
Bazar Samiti & 5 & \\
Agamkuan & 5 & \\
\hline
\end{tabular}

margin etc. were qualitatively measured (Bai et al. 2010). Further, identification was done using Gram's staining reaction.

\section{Biochemical Analysis of the Isolated Strains}

Various biochemical tests such as catalase, coagulase, mannitol motility, citrate utilization, indole and methyl red were done to identify the bacterial strains (Sarker et al. 2018)

\section{Antibiotic Sensitivity Test}

Three isolates selected from three different genera were subjected to antibiotic sensitivity test using the disk diffusion method (Poonia et al. 2014). After the incubation at $37^{\circ} \mathrm{C}$ for 24 hours, plates were examined and zones of inhibition were measured with the help of millimetre scale from the edge to the disc.

\section{RESULTS}

\section{Total Viable Count (TVC) of Different Samples of Guava}

The bacterial load found to be highest in Patliputra colony sample $\left(8.6 \times 10^{3}\right)$ followed by Agamkuan $\left(6.9 \times 10^{3}\right)$, Boring road $\left(6.3 \times 10^{3}\right)$ and Kankarbagh $\left(5.9 \times 10^{3}\right)$ while Bazar Samiti sample $\left(5.3 \times 10^{3}\right)$ recorded the lowest count. The bacterial load in the guava samples (Fig. 1) sold at different market places of Patna noted varied TVC (Table 2 \& Fig. 2).

\section{Isolation of Bacteria from Guava Surface Samples and Their Morphological Characterization}

The isolated microorganisms were visualized under the

Table 2: TVC of different guava samples.

\begin{tabular}{|ll|}
\hline Markets name & TVC $(\mathrm{CFU} / \mathrm{mL})$ \\
\hline Patliputra colony & $8.6 \times 10^{3}$ \\
Kankarbagh & $5.9 \times 10^{3}$ \\
Boring road & $6.3 \times 10^{3}$ \\
Bazar samiti & $5.3 \times 10^{3}$ \\
Agamkuan & $6.9 \times 10^{3}$ \\
\hline
\end{tabular}

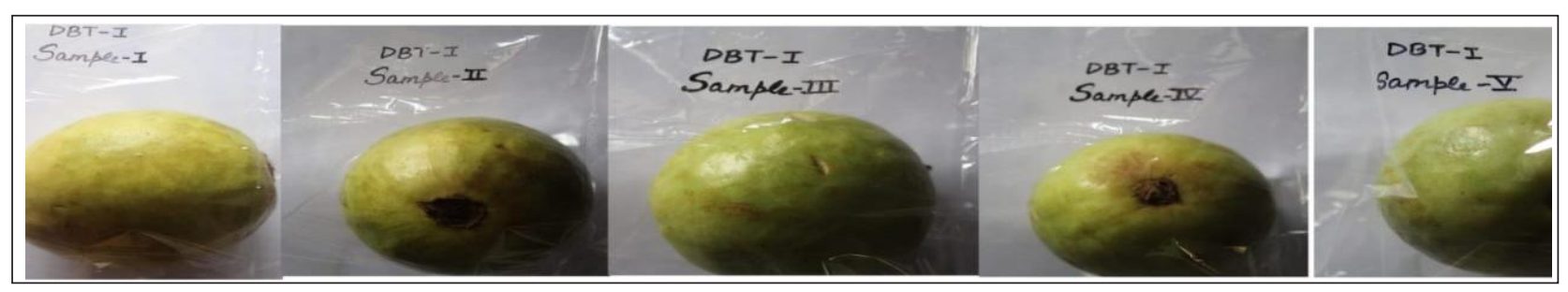

Fig. 1: Guava samples collected from local markets of Patna for bacterial isolation. 


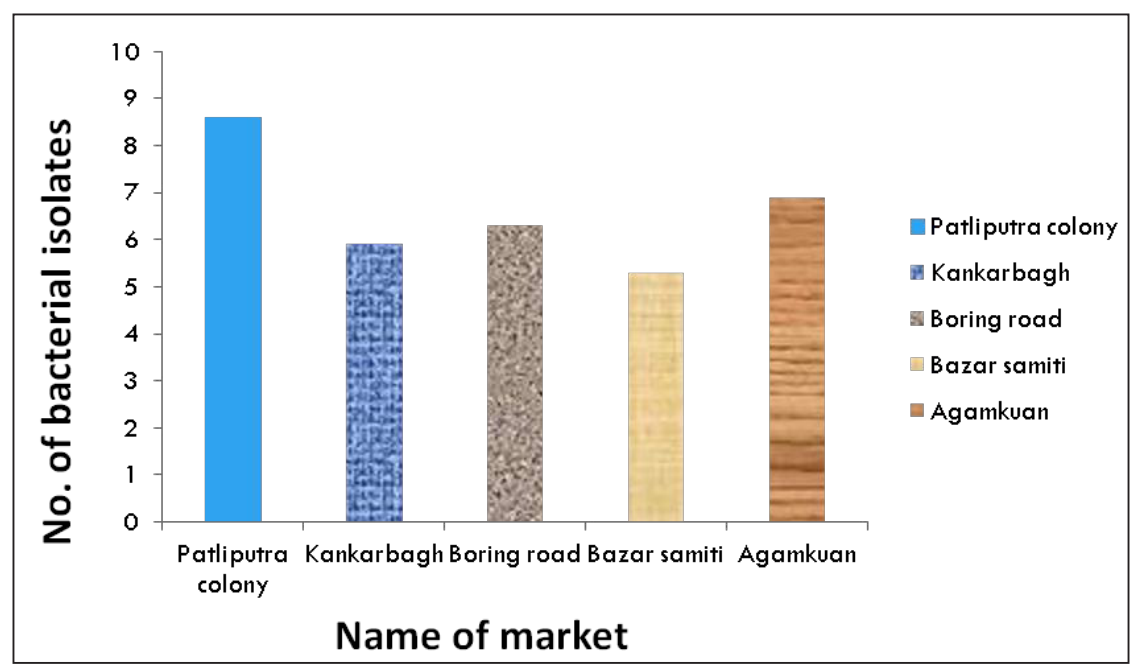

Fig. 2: Number of bacteria isolated from different guava samples.

light microscope for morphological characterization. Five different bacterial isolates were identified and further characterization was done. The bacteria isolate $\mathrm{S} 1$ and $\mathrm{S} 3$ were Gram-positive and coccus in shape while the bacteria $\mathrm{S} 2$ was Gram-negative, rod-shaped. The bacterial isolates S4 and S5 were Gram-positive rod-shaped (Table 3).

\section{Biochemical Characterization}

The biochemical test results of the isolated bacteria from different guava samples are given in Table 4.

\section{Antibiotic Sensitivity Tests}

All the five isolates identical to Staphylococcus spp. (S1 and S3), Escherichia coli (S2), and Bacillus spp. (S4 and S5) were subjected to antibiotic sensitivity test. To detect the sensitivity pattern of all the isolates, the CLSI (Clinical and Laboratory Standard Institute) standards have been used. The present study revealed, S1 and S3 resistant to ampicillin, chloramphenicol, ofloxacin and intermediate to gentamycin while S2 resistant to ampicillin, chloramphenicol, gentamy-

Table 3: Morphological characteristics of different isolates.

\begin{tabular}{|llllll|}
\hline Bacterial isolates & Colour & Texture & Elevation & Margin & Shape \\
\hline S1 & White & Creamy & Flat & Circular & Coccus \\
S2 & Greyish White & Shiny & Concave & Circular & Circular \\
S3 & White & Creamy & Flat & Coccus \\
S4 & White & Creamy & Concave & Rod-shaped & Irregular \\
S5 & White & Creamy & Concave & Rod-shaped \\
\hline
\end{tabular}

Table 4: Biochemical characteristics of different isolates.

\begin{tabular}{|c|c|c|c|c|c|}
\hline Basic characteristics & $\mathrm{S} 1$ & $\mathrm{~S} 2$ & $\mathrm{~S} 3$ & S4 & S5 \\
\hline Gram staining & $\mathrm{G}+\mathrm{ve}$, coccus & G-ve, rods & $\mathrm{G}+\mathrm{ve}$, coccus & $\mathrm{G}+\mathrm{ve}$, rods & G+ve, rods \\
\hline Catalase & $+\mathrm{ve}$ & $+\mathrm{ve}$ & $+\mathrm{ve}$ & $+\mathrm{ve}$ & $+\mathrm{ve}$ \\
\hline Coagulase & $+\mathrm{ve}$ & -ve & $+\mathrm{ve}$ & -ve & -ve \\
\hline Motility & $+\mathrm{ve}$ & $+\mathrm{ve}$ & $+\mathrm{ve}$ & -ve & -ve \\
\hline Citrate & $+\mathrm{ve}$ & -ve & $+\mathrm{ve}$ & $+\mathrm{ve}$ & $+\mathrm{ve}$ \\
\hline Indole & -ve & $+\mathrm{ve}$ & -ve & $+\mathrm{ve}$ & $+\mathrm{ve}$ \\
\hline MR (Methyl Red) & $+\mathrm{ve}$ & $+\mathrm{ve}$ & $+\mathrm{ve}$ & -ve & -ve \\
\hline Interpretation & Staphylococcus spp. & Escherichia coli & Staphylococcus spp. & Bacillus spp. & Bacillus spp. \\
\hline
\end{tabular}


cin, ciprofloxacin, cephalexin and intermediate to ofloxacin while the isolates S4 and S5 were sensitive to gentamycin, intermediate to chloramphenicol and resistant to ciprofloxacin as shown in Table 5 and Figs. $3 \& 4$.

\section{DISCUSSION}

Guava is the fourth largest selling or consuming fruits in India after mangoes, bananas and citrus fruits. In the present

Table 5: Antibiotic sensitivity results of (a) S1 and S3, (b) S2 and (c) S4 and S5.

(a)

\begin{tabular}{|llllll|}
\hline Antibiotics & Disc amount $(\mu \mathrm{g})$ & Zone of resistant $(\mathrm{mm})$ & Zone of susceptible $(\mathrm{mm})$ & Isolate 1 & Inference \\
\hline Ampicillin (AM) & 10 & $<$ or $=28$ & $=29$ & 9 & Resistant \\
Gentamycin (GM) & 30 & $<$ or $=12$ & $=15$ & $=18$ & Intermediate \\
Chloramphenicol (C) & 30 & $<$ or $=12$ & $=21$ & 8 & Resistant \\
Ciprofloxacin (CIP 5) & 5 & $<$ or $=15$ & $=18$ & 6 & 0 \\
Ofloxacin (OF) & 5 & $<$ or $=14$ & $=18$ & 5 \\
Cephalexin (CLX) & 30 & $<$ or $=14$ & & Resistant \\
\hline
\end{tabular}

(b)

\begin{tabular}{|c|c|c|c|c|c|}
\hline Antibiotics & Disc amount $(\mu \mathrm{g})$ & Zone of resistant $(\mathrm{mm})$ & Zone of susceptible (mm) & Isolate 2 & Inference \\
\hline Ampicillin (AM) & 10 & $<$ or $=11$ & $=14$ & 9 & Resistant \\
\hline Gentamycin (GM) & 30 & $<$ or $=12$ & $=15$ & 10 & Resistant \\
\hline Chloramphenicol (C) & 30 & $<$ or $=12$ & $=18$ & 9 & Resistant \\
\hline Ciprofloxacin (CIP-5) & 5 & $<$ or $=15$ & $=21$ & 12 & Resistant \\
\hline Ofloxacin (OF) & 5 & $<$ or $=14$ & $=18$ & 15 & Intermediate \\
\hline Cephalexin (CLX) & 30 & $<$ or $=14$ & $=18$ & 10 & Resistant \\
\hline
\end{tabular}

(c)

\begin{tabular}{|c|c|c|c|c|c|}
\hline Antibiotic & Disc amount $(\mu \mathrm{g})$ & Zone of resistant (mm) & Zone of susceptible (mm) & Isolate 3 & Inference \\
\hline Ampicillin (AM) & 10 & $<$ or $=11$ & $=14$ & 12 & Intermediate \\
\hline Gentamycin (GM) & 30 & $<$ or $=12$ & $=15$ & 20 & Susceptible \\
\hline Chloramphenicol (C) & 30 & $<$ or $=12$ & $=18$ & 15 & Intermediate \\
\hline Ciprofloxacin (CIP 5) & 5 & $<$ or $=15$ & $=21$ & 14 & Resistant \\
\hline Ofloxacin (OF) & 5 & $<$ or $=14$ & $=18$ & 13 & Intermediate \\
\hline Cephalexin (CLX) & 30 & $<$ or $=14$ & $=18$ & 4 & Resistant \\
\hline
\end{tabular}

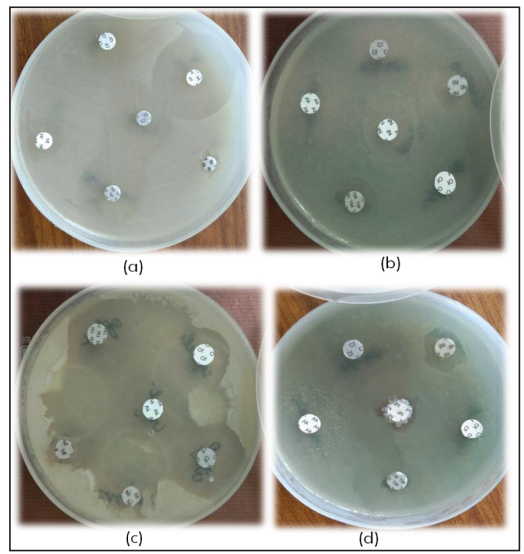

Fig. 3: Antibiotic sensitivity test of (a) (b) S1 and S3, (c) S2 and (d) S4 and S5.

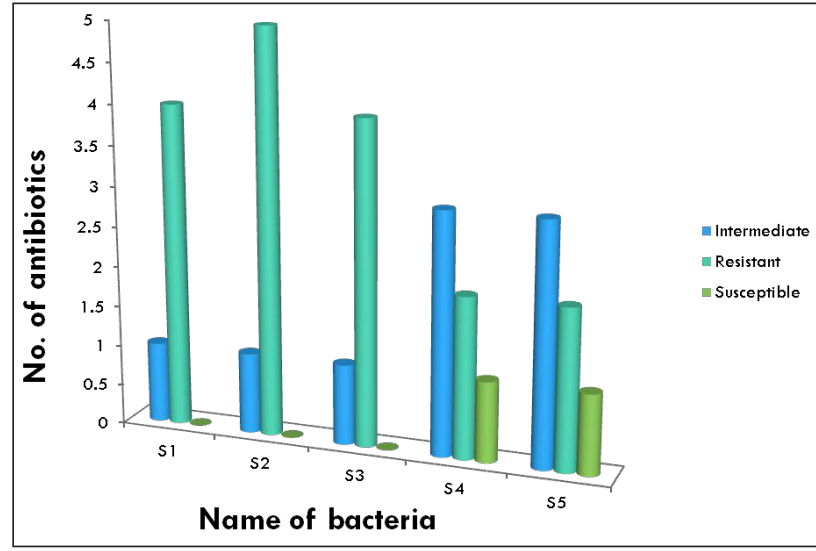

Fig. 4: Summary of antibiogram profile of isolates similar to Staphylococcus spp. (S1 and S3), E. coli (S2) and Bacillus spp. (S4 and S5). 
study, twenty five samples of guava, all procured from different market places of Patna, were used and isolation, characterization and identification of microbes (bacteria) were made. The identified bacterial isolates were found identical to three genera such as Staphylococcus spp., Escherichia coli, Bacillus spp. Most of the guava samples were found contaminated with foodborne bacteria because of the poor hygiene and handling practices performed by the vendors (Gultie et al. 2013). This might have resulted in the occurrence of antibiotic resistant bacteria which could cause diseases among its consumers.

Three bacterial isolates of guava in this study were found resistant to different antibiotics that were used during the antibiotic sensitivity test. S1 and S3 resistant to ampicillin, chloramphenicol, ofloxacin and intermediate to gentamycin while $S 2$ resistant to ampicillin, chloramphenicol, gentamycin, ciprofloxacin, cephalexin and intermediate to ofloxacin and the isolates S4 and S5 were sensitive to gentamycin, intermediate to chloramphenicol and resistant to ciprofloxacin.

The present investigation further revealed that the bacterial isolates that had been isolated from guava were found almost multidrug resistant. The occurrence of these multidrug resistant bacteria is the consequence of antibiotics either used in agricultural practises (Falkiner 1998) or used as animal manure in the agricultural fields (Boehme et al. 2004). Therefore, it can be suggested that implementation of proper hygienic conditions during pre- and post-harvest stages of production, transportation, storage and selling of the food stuffs for the safeguard of public health (Sarker et al.2018).

\section{CONCLUSION}

This study has clearly shown the presence of antibiotic resistant bacteria in the guava samples procured from local markets of Patna, Bihar. These multidrug resistant bacterial isolates could lead to health hazards for the consumers and their presence is of major health concern.

\section{ACKNOWLEDGMENTS}

Financial assistance from the Department of Biotechnology, Government of India under DBT Star College Scheme is thankfully acknowledged.

\section{REFERENCES}

Andrews, J.H. and Harris, F.R. 2000. The ecology and biogeography of microorganisms on plant surfaces. Annual Review of Phytopathology, 38: 145-180.

Bai, N., Bae, E., Bhunia, A., Robinson, J. and Hirleman, E. 2010. Morphology characterization of bacterial colonies for predicting forward scattering patterns. Advanced Photonics and Renewable Energy, OSA Technical Digest (CD) (Optical Society of America,), paper STuC4.

Balotescu, C., Israil, A., Radu, R., Alexandru, I. and Dobre, G. 2000. Aspects of constitutive and required antibiotic resistance in Aeromonas hydrophilia strains isolated from water sources. Roum. Arch. Microbio. Immunol., 62: 179-89.

Boehme, S., Werner, G., Klare, I., Reissbrodt, R. and Witte, W. 2004. Occurrence of antibiotic-resistant Enterobacteria in agricultural foodstuffs. Mol. Nutr. Food Res., 48: 522-531.

Brugger, S.D., Baumberger, C., Jost, M., Jenni, W., Brugger, U. and Muhlemann, K. 2012. Automated counting of bacterial colony forming units on agar plates. PloS One, 7(3): e33695.

Dinesh, M.R. and Vasugi, C. 2010. Guava improvement in India and future needs. Journal of Horticultural Sciences, 5(2): 94-108.

Falkiner, F.R. 1998. The consequence of antibiotics used in horticulture. J. Antimicrob. Chemother., 41: 429-431.

Gultie, A. and Sahile, S. 2013. Microbial spectrum of fruit in Gondar town markets, North Western Ethiopia. J. Microbiol. Res., 3: 1-10.

Islam, N.N., Nur S., Farzana, Z., Uddin, I., Kamaruddin, K.M. and Siddiki, A.M.A.M.Z. 2014. Rapid identification of eosin methylene blue positive Escherichia coli by specific PCR from frozen chicken rinse in southern Chittagong city of Bangladesh: Prevalence and antibiotic susceptibility. Microbiology Journal, 4(2): 27-40.

Janisiewicz, W. and Korsten, L. 2002. Biological control of postharvest diseases of fruits. Annual Review of Phytopathology, 40(1): 411-41.

Kaneria, M. and Chanda, S. 2011. Phytochemical and pharmacognostic evaluation of leaves of Psidium guajava (Myrtaceae). Pharmacognosy Journal, 3(23): 41-45.

Poonia, S., Singh, T.S. and Tsering, D.C. 2014. Antibiotic susceptibility profile of bacteria isolated from natural sources of water from rural areas of East Sikkim. Indian Journal of Community Medicine, 11(8): $1145-1149$.

Sarker, M.A.R., Haque, M.M., Rifa, R.A., Ema, F.A., Islam, M.A. and Khatun, M.M. 2018 Isolation and identification of bacteria from fresh guava (Psidium guajava) sold at local markets in Mymensingh and their antibiogram profile. Vet World, 11(8): 1145-1149.

Sanders, E.R. 2012. Aseptic laboratory techniques: Plating method. Journal of Visualized Experiments, 63: 30-64.

Sharma, R., Sharma, C.L. and Kapoor, B. 2005. Antibacterial resistance: Current problems and possible solution. Indian J. Med. Science, 59: 120-129.

Shruthi, S.D., Roshan, A., Timilsina, S.S. and Sunita, S. 2013. A review of the medicinal plant Psidium guajava Linn. (Myrtaceae). J. Drug Deliv., 3(2): 162-168.

Viswanathan, V.K. 2014. Off label abuse of antibiotics by bacteria. Gut Microbes, 5(1): 3-4. 